\title{
Geochemistry and Fe Isotope compositions of Modern Soils developed on Late Archean granites around Hyderabad, southern India
}

\author{
GUGULOTHU BALU ${ }^{1}$ AND BULUSU SREENIVAS ${ }^{2}$
}

${ }^{1}$ CSIR-National Geophysical Research Instistute

${ }^{2}$ CSIR-National Geophysical Research Institute

Presenting Author: gbalungri@ngri.res.in

The Hyderabad granitic region $(\sim 2.5 \mathrm{Ga})$ is part of the Precambrian peninsular shield and covering over the Eastern Dharwar Craton (EDC), considered the largest granitic pluton of the Indian subcontinent. The Hyderabad Granites are incipient to moderate weathered; the residual soils are developed by the pedogenic process, under semi-arid with sub-tropical climatic conditions. The soil profiles were sampled from fresh road cuts contains topsoil to fresh basement rock with specific intervals. The primary mineral compositions of these granites are $\mathrm{K}$ feldspar $(34 \%-60 \%)$, quartz $(21 \%-42 \%)$, and plagioclase (2\%-30\%) with biotite (1\%-22\%). Pyroxene, epidote apatite, and opaque are constitute as minor in this region.

The soils developed on Hyderabad granite exhibit enrichment in $\mathrm{Al}_{2} \mathrm{O}_{3}$ and $\mathrm{Fe}_{2} \mathrm{O}_{3}$, while $\mathrm{SiO}_{2}, \mathrm{CaO}, \mathrm{Na}_{2} \mathrm{O}$, and $\mathrm{MgO}$ show depletion with respect to the parent rocks. The Chemical Index of Alteration (CIA) values range from 52.65 to 65.39 , while the parent granites show values between 49.7 and 51.8, indicating incipient chemical weathering.

The trace and REE compositions indicate that the immobile elements such as $\mathrm{Zr}$, Hf, Th, $\mathrm{Nb}$, and REEs are slightly enriched to their respective parent rocks, whereas mobile alkali elements $\mathrm{Sr}, \mathrm{Ba}, \mathrm{Rb}$ are depleted. The REE patterns show significant negative $\mathrm{Eu}\left(\mathrm{Eu} / \mathrm{Eu}^{*}\right)$ anomaly $(0.12$ to .65$)$, with positive $\mathrm{Ce}$ anomalies $\left(\mathrm{Ce} / \mathrm{Ce}^{*}\right)$ that range from 0.65 to 1.87 .

$\mathrm{Fe}$ isotope analysis is carried out using HR-MC-ICPMS. IRMM-014 was used as standard reference material for Standard-Sample Bracketing (SSB) method, and the precision obtained is $\pm 0.05 \%$ \% $(1 \sigma)$. The $\delta^{56} \mathrm{Fe} \quad$ IRMM-014 $\left[\left\{\left({ }^{56} \mathrm{Fe} /{ }^{54} \mathrm{Fe}_{\text {sample }}\right) /\left({ }^{56} \mathrm{Fe} /{ }^{54} \mathrm{Fe}\right.\right.\right.$ IRMM-014) -1$\left.\} \times 1000\right]$ of the unaltered Hyderabad granites are slightly enriched and show a range of values from 0.21 to $0.22 \%$. The soil samples collected from 3 different profiles vary between 0.11 and 0.31 . The overall $\delta^{56} \mathrm{Fe}$ variations in the incipiently weathered soil profiles developed on Hyderabad granite show minimal variation compared to their parent rock. 